DOI: 10.17707/AgricultForest.63.1.05

\author{
Metodija TRAJCHEV, Dimitar NAKOV, \\ Milena PETROVSKA, Gordana JANKOSKA ${ }^{I}$
}

\title{
MASTITIS PATHOGENS AND THEIR ANTIMICROBIAL SUSCEPTIBILITY IN EARLY LACTATING DAIRY COWS
}

\section{SUMMARY}

A two years cross-sectional longitudinal survey was carried out for determination of udder pathogens prevalence and their antimicrobial profile in one commercial dairy farm. Dairy cows were selected in relation to date of calving and period of early lactation in order to minimize environmental impact. A udder quarters milk samples were obtained from totally 211 black-white dairy cows. The quarter milk-samples were screening using the California Mastitis Test (CMT) for detection of abnormal milk secretion (AMS) and from quarters with AMS were obtained milk-samples for microbiological examination in order to detect intramammary infections (IMI). The milk-samples were obtained in two periods: period from beginning of lactation until $21^{\text {st }}$ day in lactation and period from $22^{\text {nd }}$ to $42^{\text {nd }}$ day in lactation. The prevalence of IMI in period from beginning of lactation until $21^{\text {st }}$ day in lactation and period from $22^{\text {nd }}$ to $42^{\text {nd }}$ day in lactation was $4.03 \%$ and $4.38 \%$, respectively. Based on CMT, there was found totally 162 udder quarters with AMS. From these quarters, the overall proportion of microbiological negative quarters was $56.17 \%$ and mastitis pathogens were isolated from $43.83 \%$ of udder quarters, from which the dominant mastitis pathogens were: Streptococcus agalactiae (19.14\%), Enterococcus spp. (8.02\%), Candida non-albicans (6.79\%), Staphylococcus aureus (6.17\%), Escherichia coli (1.85\%), Aspergilus niger (1.23\%) and Pseudomonas aeruginosa (0.62\%). The results indicated that contagious pathogens were the most common patogens of IMI in early lactation. There was significant difference in the prevalence of intramammary infection $\left(\chi^{2}=35.136, \mathrm{df}=1, \mathrm{p}<0.001\right)$ when comparing the front and rear udder quarters. The isolated bacteria were examined for determination of susceptibility to 27 most used antimicrobial agents for mastitis treatment. The most resistant strain was Staphylococcus aureus.

Keywords: dairy cow, intramammary infection, lactation

\section{INTRODUCTION}

Maintaining adequate herd health remains a major issue for the majority of dairy herds, and is an area where constant attention to detail is required.

\footnotetext{
${ }^{1}$ Metodija Trajchev (corresponding author: metot@fznh.ukim.edu.mk), Dimitar Nakov University „St. Cyril and Methodius“,Faculty of Agricultural Sciences and Food, Institute of Animal Biotechnology, Department of Animal Health and Animal Welfare, Skopje, Republic of MACEDONIA Milena Petrovska, Gordana Jankoska University „St. Cyril and Methodius“, Medical Faculty, Institute of Microbiology with Parasitology Skopje, Republic of MACEDONIA Paper presented at the $7^{\text {th }}$ International Scientific Agricultural Symposium "AGROSYM 2016".

Notes: The authors declare that they have no conflicts of interest. Authorship Form signed online.
} 
Parturition and the onset of lactation represent the most hazardous periods of drastic physiological changes and intense metabolic demands in dairy cows which leads to increased incidence of metabolic disorders and infectious diseases (Sordillo and Aitken, 2009). Equally as important but however, mastitis in dairy cows are the most important diseases of the mammary gland which incidence increases as a consequence of parturition when host defense mechanisms are compromised. Mastitis has high economic implications due to losses in milk production and the risk posed by consumption of infected milk to public health. Bacterial infection and growth in the udder is the main cause of bovine mastitis. More than 150 Gram (+) and Gram (-) bacteria are identified as mastitis pathogens. However, the most prevalent mastitis pathogens are coagulase $(+)$ and coagulase (-) bacteria from genus Staphylococcus, than bacteria from genus Streptococcus and Gram (-) Coliforms, especially Escherichia coli (Contreras and Rodriguez, 2011). However, approximately $10-40 \%$ of clinical mastitis cases yield "no significant growth" in routine clinical culture assays, and one study has also indicated that the number of such cases may be on the rise, although the reason for this is not currently known (Persson et al., 2011).

Traditionally, all udder pathogens have been classified as either 'contagious' or 'environmental', depending on their primary behavior and their route of transmission (White et al., 2006). The major contagious udder pathogens on dairy farms are: Staphylococcus aureus, Streptococcus agalactiae и Mycoplasma bovis (Trajcev et al., 2009). There are a wide range of environmental opportunistic pathogens that caused mastitis: Escherichia coli, Klebsiella spp., Enterobacter spp., Serratia spp., Pseudomonas spp., Proteus spp., Corynebacterium pyogenes, Streptococcus uberis and Streptococcus dysgalactiae, else more coagulase (-) bacteria from genus Staphylococcus (Taponem and Pyorala, 2009). However, Piessens et al. (2012) revealed that this dichotomous in transmission of udder pathogens is loosing and from epidemiological aspect there is no strict border between contagious and environmental mastitis.

According the literature data from around the world, the prevalence of udder pathogens that cause subclinical and clinical mastitis can vary widely (Ericsson et al., 2009; Persson et al., 2011). In the past, the most common udder pathogens in dairy herds were Streptococcus agalactiae and Staphylococcus aureus. However, the adoption of modern milking practices and implementation of the mastitis control programs has resulted in a considerable decline in the prevalence of these organisms in many modern dairy farms (Makovec and Ruegg, 2003). Today, the common environmental organisms include CNS, Streptococcus uberis, Streptococcus dysgalactiae, Klebsiella spp., and Escherichia coli (Taponen and Pyorala, 2009).

The most common udder pathogens from subclinical cases of mastitis in dairy farms in Republic of Macedonia were Streptococcus agalactiae, Staphylococcus aureus, Enterococcus spp and environmental Streptococcus spp (Trajcev et al., 2010). 
The literature data differ significantly in reporting the prevalence of etiological agent for mastitis depending from the region where the surveys were done. For example, the prevalence of Staphylococcus aureus in Finland and Germany vary from 3,0 to $3,5 \%$ up to $38,5 \%$ in Zimbabwe and Australia (Kloppert et al., 1999; Milne et al., 2002). Kalmus et al. (2011) reported that Streptococcus agalactiae is the second predominant etiological agents of mastitis in dairy farms but cure rate with antibiotic therapy during lactation is very high.

The program for prevention and eradication of mastitis in dairy herds include regular implementation of screening methods for early detection of mastitis, like California Mastitis Test (CMT), measurements of milk conductivity and the presence of chlorides and sodium in milk as results of udder inflammation (Sharma и сор., 2011). The early mastitis detection in dairy herd has many potential benefits, out of which it will allows implementation of proactive management strategies that will avoid negative effects of disease and will leads to better cure rates (Deluyker et al., 2005). Several studies have reported an increased trend over time in resistance among mastitis pathogens due to uncontrolled use of antimicrobials for mastitis treatment (Trajcev et al., 2009). There is a concern that antimicrobial therapy of mastitis in dairy cows can lead to residues occurrence in milk which are potential hazards to public health (Andersson et al., 2011).

The objective of this study was to identify the udder pathogens in one dairy herd in period of early lactation and to determine their antimicrobial susceptibility. in order to establish a more effective therapy for udder infections.

\section{MATERIALS AND METHODS}

A two year longitudinal survey in period from $1^{\text {st }}$ of April, 2012 until $31^{\text {st }}$ of March, 2014, was carried out for determination of udder pathogens prevalence and their antimicrobial profile in dairy cows during the period of early lactation. The study was carried out in a conventional dairy farm localized near city of Strumica in south-eastern part of Macedonia. Totally, 211 primiparous and multiparous black-white dairy cows in beginning of lactation were selected. The dairy cows were allocated into groups related to the season of calving in order to minimize the influence of environment on mastitis pathogens prevalence. Cows were kept in the same farm providing with similar house conditions and feeding regime during 2 years of experiment to exclude the influence of additional environmental factors, such as feeding. Cows consumed ordinary diet which differed in accordance with the stage of pregnancy and lactation but was the same during consecutive events and included corn and grass silage, hay, commercial concentrate (maize, wheat, barley) as well as vitamin and mineral premix. The udder health status was followed from calving to $42^{\text {nd }}$ day in lactation. This period of early lactation was subdivided into 2 periods: period from calving until $21^{\text {st }}$ day in lactation and period from $22^{\text {nd }}$ to $42^{\text {nd }}$ day in lactation. Daily, during the trial period, each cow on milking line was observed clinically for presence of clinical signs of mastitis (rubber, tumour, colour, dolour 
and function laesa) and determination of abnormalities in milk (presence of watery milk, flakes, clots, blood, pus, discoloured milk, etc). Additionally, there was used Califonia Mastitis Test (CMT) as predicted tool for detection of udder quarters with abnormal milk secretion (Schalm и Noorlander, 1957). The screening of udder health status was done on quarter level.

Samples for bacteriological culture from each quarter positive to CMT, were collected aseptically in sterile $10 \mathrm{~mL}$ tubes, without additives, according to the National Mastitis Council (Hogan et al., 1999) and kept at $4{ }^{\circ} \mathrm{C}$ during transport. Samples were analyzed within 12 hours of collection. Bacterial species were identified according standard microbiological procedure using accredited methodology based on the National Mastitis Council standards (NMC, 2001). From each sample, $10 \mu \mathrm{l}$ of milk was cultured on Columbia blood agar (Oxoid UK) for enrichment and isolation of specific udder pathogens. Parallel, $10 \mu \mathrm{l}$ of milk was cultured on STRB agar (BioMérieux - France) for isolation of $\beta$ hemolytic Streptococcus spp. group B (Smith et al., 1985). Incubation was done for $48 \mathrm{~h}$. at $37{ }^{\circ} \mathrm{C}$ and $24 \mathrm{~h}$ more on room temperature for grout of eventually present of fungi. Sometimes, for better fungi grout, the incubation was lasting up to 5 days. A minimum of five colonies of the same type of bacterium was recorded as bacteriological positive, and growth of more than two types of bacterial colonies was categorized as mixed growth. No bacterial growth was recorded when fewer than five colony-forming units were detected during $48 \mathrm{~h}$ of incubation. Based on results from screening using clinical examination, CMT and bacteriological culturing, all cows in observed population were allocated into three groups: healthy cows without udder health problems, cows with persistent abnormal milk secretion and cows with persistent intramammary infection. The difference in prevalence of IMI between front and rare udder quarters and their significance was estimated by Chi-square test.

Once they had been isolated and identified, pure cultures of udder pathogens were tested for antibacterial susceptibility with the disc diffusion assay on Mueller-Hinton agar using commercial antimicrobial discs (Oxoid - UK). Testing was performed according to the recommendation of the National Committee for Clinical Laboratory Standards (NCCLS, 2002). The list of antibiotics in susceptibility testing may vary in order to find accurate treatment after getting the laboratory test results. The criteria for the interpretation of zone of inhibition diameter were: sensitive, intermediate sensitive and resistant.

\section{RESULTS AND DISCUSSION}

The prevalence of udder quarter health disorders in observed population of dairy cows in early lactation during the two years survey is shown in Table 1.

The prevalence of udder quarters with abnormal milk secretion was $5.33 \%$ and $5.45 \%$, respectively for period from calving until $21^{\text {st }}$ day in lactation and period from $22^{\text {nd }}$ to $42^{\text {nd }}$ day in lactation. The prevalence of IMI showed the same ratio and therefore, the prevalence in the first period in lactation from calving to $21^{\text {st }}$ day in lactation was $4.03 \%$ and the prevalence in the period from $22^{\text {nd }}$ to 
$42^{\text {nd }}$ day in lactation was $4.38 \%$. The total prevalence of udder health disorders on quarter level was $9.36 \%$ and $9.83 \%$, respectively for period from calving until $21^{\text {st }}$ day in lactation and period from $22^{\text {nd }}$ to $42^{\text {nd }}$ day in lactation.

Table 1. The prevalence of udder health disorders in dairy cows on quarter level in two periods of early lactation

\begin{tabular}{|c|c|c|c|c|c|c|c|c|c|}
\hline \multirow{2}{*}{ Period } & Total & \multicolumn{2}{c|}{ CMT(-) } & \multicolumn{2}{c|}{ CMT(+) } & \multicolumn{2}{|c|}{ AMS } & \multicolumn{2}{|c|}{ IMI } \\
\cline { 2 - 9 } & $\mathbf{n}$ & $\mathbf{n}$ & $\mathbf{\%}$ & $\mathbf{n}$ & $\mathbf{\%}$ & $\mathbf{n}$ & $\mathbf{\%}$ & $\mathbf{n}$ & $\mathbf{\%}$ \\
\hline Day_21 & 844 & 765 & 90,64 & 79 & 9,36 & 45 & 5,33 & 34 & 4,03 \\
\hline Day_42 & 844 & 761 & 90,17 & 83 & 9,83 & 46 & 5,45 & 37 & 4,38 \\
\hline
\end{tabular}

In Table 2 is shown the ratio between udder quarters with IMI versus udder quarters that have positive CMT reaction depending from quarters udder position.

Table 2. The ratio between IMI and AMS on udder quarter level regarding their udder position

\begin{tabular}{|c|c|c|c|c|c|c|c|c|c|c|c|c|c|c|c|}
\hline \multicolumn{4}{|c|}{ Total quarters } & \multicolumn{3}{|c|}{ FL } & \multicolumn{3}{c|}{ FR } & \multicolumn{3}{c|}{ RL } & \multicolumn{3}{c|}{ RR } \\
\hline Period & CMT & IMI & $\begin{array}{c}\text { IMI } \\
(\%)\end{array}$ & CMT & IMI & $\begin{array}{c}\text { IMI } \\
(\%)\end{array}$ & CMT & IMI & $\begin{array}{c}\text { IMI } \\
(\%)\end{array}$ & CMT & IMI & $\begin{array}{c}\text { IMI } \\
(\%)\end{array}$ & CMT & IMI & $\begin{array}{c}\text { IMI } \\
(\%)\end{array}$ \\
\hline $\begin{array}{c}\text { Day } \\
21\end{array}$ & 79 & 34 & 43,04 & 16 & 6 & 37,50 & 16 & 10 & 62,50 & 20 & 6 & 30,00 & 27 & 12 & 44,44 \\
\hline $\begin{array}{c}\text { Day } \\
42\end{array}$ & 83 & 37 & 44,58 & 17 & 8 & 47,06 & 19 & 10 & 52,63 & 28 & 10 & 35,71 & 19 & 9 & 47,37 \\
\hline
\end{tabular}

Generally, the rare udder quarters are more prevalent to have IMI in relation with front quarters. There was statistically significant difference in prevalence of IMI in rare udder quarters than front udder quarters $\left(\chi^{2}=35.136\right.$, $\mathrm{df}=1, \mathrm{p}<0.001)$. Table 3 represents the distribution of udder pathogens in milk samples from udder quarters with abnormal milk secretion that showed positive reaction to CMT.

Table 3. Udder pathogens isolated in milk sample from quarters with positive CMT

\begin{tabular}{|c|c|c|c|c|c|}
\hline & $\mathrm{n}$ & $\%$ & & \multirow{3}{*}{$\mathbf{n}$} & \multirow{3}{*}{$\%$} \\
\hline CMT (+) quarters & 162 & 100,00 & & & \\
\hline Microbiologically negative & 91 & 56,17 & & & \\
\hline \multirow{7}{*}{ Microbiologically positive } & \multirow{7}{*}{71} & \multirow{7}{*}{43,83} & Streptococcus agalactiae & 31 & 19,14 \\
\hline & & & Enterococcus Spp. & 13 & 8,02 \\
\hline & & & Candida non-albicans & 11 & 6,79 \\
\hline & & & Staphylococcus aureus & 10 & 6,17 \\
\hline & & & Escherichia coli & 3 & 1,85 \\
\hline & & & Aspergillus niger & 2 & 1,23 \\
\hline & & & Pseudomonas aeruginosa & 1 & 0,62 \\
\hline
\end{tabular}


During the two year observation of dairy cow population, there was found 162 udder quarters that have abnormal milk secretion and showed positive reaction on CMT out of totally 844 tested quarters. Of them, $56.17 \%$ were microbiologically negative and $43.83 \%$ microbiologically positive: Streptococcus agalactiae was isolated in milk samples from $19.14 \%$ quarters, Enterococcus spp. in 8,02\%, Candida non-albicans in 6,79\%, Staphylococcus aureus in 6,17\%, Escherichia coli in 1,85\%, Aspergilus niger in 1,23\% and Pseudomonas aeruginosa was isolated in milk samples from $0,62 \%$ of quarters.

Antimicrobial sensitivity of isolated udder pathogens is shown in Table 4.

Table 4. Antimicrobial susceptibility of udder pathogens

\begin{tabular}{|c|c|c|c|c|c|c|}
\hline & & $\begin{array}{c}\text { Str. } \\
\text { agalactiae }\end{array}$ & $\begin{array}{c}\text { St. } \\
\text { aureus }\end{array}$ & E. coli & $\begin{array}{c}\text { Enterococcus } \\
\text { spp. }\end{array}$ & $\begin{array}{c}\mathbf{P} . \\
\text { aeruginosa }\end{array}$ \\
\hline \multirow{6}{*}{$\beta$-laktam } & Penicillin (10 IU) & $\mathrm{S}$ & $\mathrm{R}$ & & $\mathrm{S}$ & \\
\hline & Ampicillin $(10 \mu \mathrm{g})$ & $S$ & $\mathrm{R}$ & I & $S$ & \\
\hline & Amoxicillin $(10 \mu \mathrm{g})$ & $S$ & I & $\mathrm{R}$ & $S$ & \\
\hline & Amoxyclav $(20 / 10 \mu \mathrm{g})$ & $S$ & $S$ & $S$ & $S$ & $\mathrm{R}$ \\
\hline & Imipenem $(10 \mu \mathrm{g})$ & & & $\mathrm{S}$ & & $\mathrm{S}$ \\
\hline & Meropenem $(10 \mu \mathrm{g})$ & & & $S$ & & $\mathrm{~S}$ \\
\hline Glycopeptid & Vancomicin $(30 \mu \mathrm{g})$ & & $S$ & & $S$ & \\
\hline $\begin{array}{l}\text { Ureidopenicillin } \\
+\beta \text {-laktam }\end{array}$ & $\begin{array}{l}\text { Piperacilin-tazobactam } \\
(100 / 10 \mu \mathrm{g})\end{array}$ & & & S & & $\mathrm{S}$ \\
\hline \multirow{2}{*}{ Aminoglycosid } & Gentamicin $(10 \mu \mathrm{g})$ & & & $S$ & $\mathrm{I}$ & $\mathrm{S}$ \\
\hline & Amikacin $(30 \mu \mathrm{g})$ & & $S$ & $\mathrm{~S}$ & & $\mathrm{~S}$ \\
\hline \multirow{2}{*}{ Cephalosporin I } & 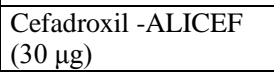 & $\mathrm{S}$ & $\mathrm{S}$ & S & & \\
\hline & Cefalexin & $S$ & & I & & \\
\hline \multirow{6}{*}{$\begin{array}{l}\text { Cephalosporin } \\
\text { III }\end{array}$} & \begin{tabular}{|l}
$\begin{array}{l}\text { Cefpodoxime } \\
(\text { TRICEF) }(10 \mu \mathrm{g})\end{array}$ \\
\end{tabular} & $\mathrm{S}$ & $\mathrm{S}$ & & & \\
\hline & Cefuroxim $(30 \mu \mathrm{g})$ & & $\mathrm{R}$ & $S$ & & $\mathrm{R}$ \\
\hline & Ceftriaxon $(30 \mu \mathrm{g})$ & $S$ & $S$ & $S$ & & $S$ \\
\hline & Cefotaxim $(30 \mu \mathrm{g})$ & $S$ & $S$ & $S$ & & S \\
\hline & Ceftazidim $(30 \mu \mathrm{g})$ & & & $S$ & & $\mathrm{~S}$ \\
\hline & $\begin{array}{l}\text { Cefixim (Pancef) (5 } \\
\mu \mathrm{g})\end{array}$ & & $\mathrm{R}$ & $\mathrm{S}$ & & $\mathrm{R}$ \\
\hline Cefalosporini IV & Cefepim $(30 \mu \mathrm{g})$ & & & $S$ & & $\mathrm{~S}$ \\
\hline Linkosamid & Clindamycin $(2 \mu \mathrm{g})$ & $S$ & $S$ & & & \\
\hline \multirow{3}{*}{ Macrolid } & Erythromycin $(15 \mu \mathrm{g})$ & $S$ & $S$ & & $\mathrm{I}$ & \\
\hline & Azithromycin $(15 \mu \mathrm{g})$ & $\mathrm{S}$ & $\mathrm{S}$ & & & \\
\hline & Clarithromycin $(5 \mu \mathrm{g})$ & $S$ & & & & \\
\hline $\begin{array}{l}\text { Trimethoprim + } \\
\text { Sulfamethoxasol }\end{array}$ & $\begin{array}{l}\text { Co-trimoxazol } \\
(1,25 / 23,75 \mu \mathrm{g})\end{array}$ & $\mathrm{R}$ & $S$ & I & & $\mathrm{R}$ \\
\hline \multirow{2}{*}{ Fluoroquinolon } & Ciprofloxacin $(5 \mu \mathrm{g})$ & $\mathrm{S}$ & $\mathrm{S}$ & $S$ & $S$ & $S$ \\
\hline & Moxifloxacin $(5 \mu \mathrm{g})$ & $S$ & & & & \\
\hline Polymyxin & Colistin $(10 \mu \mathrm{g})$ & & & $\mathrm{S}$ & & $\mathrm{S}$ \\
\hline
\end{tabular}


The isolates of Streptococcus agalactiae were mostly susceptible to antimicrobials tested, with exception to Co-trimoxazol from the group of Trimethoprim+Sulfamethoxasol.

The isolates of Staphylococcus aureus were resistant to most of the antimicrobials. The isolates were resistant to Penicillin, Ampicillin, Cefuroxim, Cefixim, partly susceptible to Amoxicillin and showed susceptibility to the other antimicrobials tested.

The isolates of Escherichia coli were resistant to Amoxicillin, intermediate susceptible to Ampicillin, Cefalexin and Co-trimoxazol. The isolates were susceptible to the other antimicrobials tested.

The isolates of Enterococcus spp. were intermediate susceptible to Gentamicin and Erythromycin, while the isolates were susceptible to other antimicrobials tested.

Pseudomonas aeruginosa was resistant to Amoxyclav, Cefuroxim, Cefixim and Co-trimoxazol, while the isolate was susceptible to other antimicrobials tested.

Accurate mastitis detection and effective mastitis control strategies has a influent economic impact in dairy farms followed by sustainable milk production (Wallace et al., 2002).

In general, there is no ideal screening test for prompt and quick diagnosis of IMI. Culturing examination is the "gold standard" for detection of infected udder quarters, but very offen this methods are very expensive, time consuming for routine screening followed by lack for on-farm assessment (Sargeant et al., 2001). However, as IMI are usually followed by an influx of leucocytes and other macrophages into the milk, an increase in its SCC (Somatic Cell Count) has been used widely as indicating mastitis.

Comparing to culturing methods and determination of SCC, the field screening methods for diagnosis of mastitis are easy and routine methods that give prior information for antibiotic treatment of infected udder quarters and early drying off. Among the others, the California Mastitis Test (CMT) is widely used for on-farm detection of mastitis in dairy herds (Sharma et al., 2011). Calderon and Rodrigues (2008) reported some insufficiency of the CMT regarding their sensitivity and specificity in determination of IMI. The main weakness of the CMT is its low specificity for determination of udder quarters infected with a major or minor mastitis pathogens. In general, the CMT is a rapid and inexpensive test to indirectly determine the somatic cell concentration in milk and is a practical, easy method for demonstrating IMI by testing milk samples on-farm.

The results obtained by Saidi (2013) showed a good correlation between the results of CMT and isolation for the identification of intra-mammary infections in cows. Other authors reported negative bacteriological findings in 17.7 to $26.5 \%$ from cases of clinical mastitis and 28.7 to $38.6 \%$ from cases of subclinical mastitis (Roesch et al., 2007).

A higher incidence of Staphylococcus spp. and Streptococcus spp. was revealed from cases of subclinical mastitis in dairy cows (Roesch et al., 2007; Kalmus et al., 2011). Saini et al. (2013) reported higher prevalence of 
environmental mastitis pathogens and Escherichia coli in dairy herds, predominantly in early lactation.

The other study (Kivaria and Noordhuizen, 2007) performed on dairy farms in Tanzania, reveled $29 \%$ microbiologically negative milk samples. From microbiologically positive samples, there were isolated Staphylococcus aureus (25,7\%), Streptococcus agalactiae (15.4\%), Klebsiella pneumonia (14.3\%), Escherichia coli (14.1\%), Pseudomonas aeruginosa (7.5\%), Streptococcus dysgalactiae (5.2\%) and Streptococcus uberis (4.2\%). The most prevalent fungus in infected mammary gland was Candida spp. (30\%).

Similar results as obtained in this research were reported in the research of Rodrigues (2006), when the most prevalent mastitis pathogens were Streptococcus agalactiae and Staphylococcus aureus, isolated in 35\% to $45 \%$ of infected udder quarters.

The recent research from Sweden reported that the most prevalent pathogens from infected mammary gland were: Staphylococcus aureus (19\%), coagulase negative Staphylococcus spp. (16\%), Streptococcus dysgalactiae (9\%), Streptococcus uberis (8\%), Escherichia coli (2.9\%) and Streptococcus spp. $(1,9 \%)$. The rate of microbiologically negative samples was $22 \%$ from udder quarters that have positive reaction on CMT (Persson и сор., 2011).

The prevalence of udder pathogen microorganisms in cases of intramammary infections in dairy herds in Sicily for period 2000 to 2006, was: microbiologically negative $47.4 \%$, than coagulase negative Staphylococcus spp. (22.6\%), Staphylococcus aureus (20.6\%), Streptococcus spp. (11.1\%), Streptococcus agalactiae (2.3\%), environmental coliforms (2.9\%) and other pathogens $(5.8 \%)$ (Ferguson et al., 2007).

The study from Croatia, country with similar climatic conditions like Macedonia and similar management of dairy farms, reported that predominant pathogen microorganisms in cases of intramammary infection in period prior drying were: Streptococcus spp. Lancefield group B (7.79\%), Staphylococcus aureus (6,56\%), coagulase negative Staphylococcus spp. (2.87\%), Pseudomonas spp. $(2.46 \%)$, Streptococcus agalactiae (2.05\%), and $1.23 \%$ from intramammary infections were caused by other pathogen microorganisms (Maćešić et al., 2012).

According our research, Streptococcus agalactiae isolated from milk samples showed good sensitivity to all tested antimicrobials, with exception to Co-trimoxazol. The most resistant were isolates of Staphylococcus aureus. Other isolated microorganisms were susceptible to antimicrobials tested.

Similar results were reported by Persson et al. (2011) when the most of the isolated udder pathogens were susceptible to wide range of antimicrobials, with exception to Penicillin G. Opposite, the other authors reported the high level of resistance of udder pathogens to antimicrobials (Kalmus et al., 2011).

In the research performed on dairy farms in Iran (Ebrahimi et al., 2007), the prevalence of udder pathogens in dairy farms was as similar as in our research, while the most of isolated microorganisms showed resistance to Penicillin, Streptomycin, Oxytetracyclin and Colistin. The most of the researchers indicate on increased antimicrobial resistance between udder pathogens while Staphylococcus aureus was the most resistant microorganism (Bengtsson et al., 2009). 


\section{CONCLUSIONS}

The total prevalence of udder health disorders on quarter level was $9.36 \%$ and $9.83 \%$, respectively for period from calving until $21^{\text {st }}$ day in lactation and period from $22^{\text {nd }}$ to $42^{\text {nd }}$ day in lactation. The high prevalence of contagious udder pathogens in observed population of dairy cows indicate on bad hygienic condition during milking of cows and possibility for infection of health udder quarters through the equipment and hands of the workers. The isolates of udder pathogens were mostly susceptible to antimicrobials tested, with exception to the isolates of Staphylococcus aureus that were resistant to most of the antimicrobials.

\section{REFERENCES}

Andersson, I., Andersson, H., Christiansson, A., Lindmark-Månsson, H., Oskarsson, M., Persson, Y. and Widell, A. (2011). System analys Celltal. Stockholm: Svensk Mjölk Forskning. Nr. 7091.

Bengtsson, B., Ericsson, H.U., Ekman, T., Artursson, K., Nilsson, M., Persson, K. (2009). Antimicrobial susceptibility of udder pathogens from cases of acute clinical mastitis in dairy cows. Veterinary Microbiology 136, pg. 142-149.

Calderon, A., and Rodriguez,. V. (2008). Prevalencia de mastitis bovina y su etiologia infecciosa en sistemas especializados en produccion de leche en el altiplano cundiboyacense (Colombia). Rev. Colomb. Cienc. Pecu. 21: pg. 582-589.

Contreras, G.A. and Sordillo, L.M. (2011). Lipid mobilization and inflammatory responses during the transition period of dairy cows. Comparative Immunology, Microbiology and Infectious Diseases, 34, pg. 281-289.

Deluyker, H.A., Van Oye, S.N., Boucher, J.F. (2005). Factors affecting cure and somatic cell count after pirlimycin treatment of subclinical mastitis in lactating cows. J. Dairy Sci. 88, pg. 604-614.

Ebrahimi, A., Pirali Kheirabadi, K.H., Nikookhah, F. (2007). Antimicrobial susceptibility of environmental bovine mastitis pathogens in west central Iran. Pakistan Journal of Biological Sciences 10 (17): pg. 3014-3016.

Ericsson, U.H., Lindberg, A., Persson, W.K., Ekman, T., Artursson, K., Nilsson-Ost, M., Bengtsson, B. (2009). Microbial aetiology of acute clinical mastitis and agent-specific risk factors. Vet. Microbiol. 137: pg. 90-97.

Ferguson, J.D., Azzaro, G., Gambina, M. and Licitra, G. (2007). Prevalence of Mastitis Pathogens in Ragusa, Sicily, from 2000 to 2006. J. Dairy Sci. 90: pg. 5798-5813.

Hogan, J.S., Gonzalez, R.N., Harmon, R.J., Nickerson, S.C., Oliver, S.P., Pankey, J.W. and Smith, K.L. (1999). Testing procedures. Page 207 in Laboratory Handbook on Bovine Mastitis. 1st ed. Nat. Mastitis Counc., Inc., Madison, WI.

Kalmus, P., Auasme, B., Kurssin, A., Orro, T., Kask, K. (2011). Udder pathogens and their resistance to antimicrobial agents in dairy cows in Estonia. Acta Vet. Scand., 53, 4: pg. $1-7$.

Kivaria, F.M. and Noordhuizen, J.P.T.M. (2007). A retrospective study of the aetiology and temporal distribution of bovine clinical mastitis in smallholder dairy herds in the Dar es Salaam region of Tanzania. Vet. J 173, pg. 617-622.

Kloppert, B., Wolter, W., Risse, K. and Zschöck, M. (1999). Erregerspektrum bei boviner subklinischer Mastitis in hessischen Milcherzeugerbetrieben. In: Tagungsbericht des 23. Kongresses der Deutschen Veterinärmedizinischen Gesellschaft e.v. in Bad Nauheim. pg. 350-355.

Maćešić, N., Karadjole1, T., Bačić, G., Benić, M., Karadjole, M., Vince, S., Lipar, M. and Cergolj, M. (2012). Aetiology and prevalence of bovine intramammary infection at drying off. Vet Arh. 82 (2), pg. 125-131. 
Milne, M.H., Barrett, D.C., Fitzpatrick, J.L., Biggs, A.M. (2002). Prevalence and aetiology of clinical mastitis on dairy farms in Devon. Vet. Rec. 151, pg. 241-243.

National Committee for Clinical Laboratory Standards (NCCLS). (2002). Performance standards for antimicrobial disk and dilution susceptibility tests for bacteria isolated from animals, 2nd ed., approved standard M31-A2. NCCLS, Wayne, PA.

National Mastitis Council (NMC). (2001). National Mastitis Council Recommended Mastitis Control Program. Http://www.nmconline.org/docs/NMC10steps.pdf. 2001.

Persson, Y., Nyman, A.J. and Grönlund-Andersson, U. (2011). Etiology and antimicrobial susceptibility of udder pathogens from cases of subclinical mastitis in dairy cows in Sweden Acta Veterinaria Scandinavica, 53:36.

Piessens, V., De Vliegher, S., Verbist, B., Braem, G., Van Nuffel, A., De Vuyst, L., Heyndrickx, M., Van Coillie, E. (2012). Intra-species diversity and epidemiology varies among coagulase-negative Staphylococcus species causing bovine intramammary infections. Vet Microbiol 155: pg. 62-71.

Rodriguez, G. (2006). Comportamiento de la mastitis bovina y su impacto economico en algunos hatos de la Sabana de Bogota, Colombia. Rev. Med. Vet.12: pg. 35-55.

Roesch, M., Doherr, M.G., Schären, W., Schällibaum, M., Blum, J.V. (2007). Subclinical mastitis in dairy cows in Swiss organic and conventional production systems. J Dairy Res, 74: pg. 86-92.

Saidi, R., Khelef, D., Kaidi, R. (2013). Bovine mastitis: Prevalence of bacterial pathogens and evaluation of early screening test Afr. J. Microbiol. Res. Vol. 7(9), pg. 777-782.

Saini, V., McClure, J.T., Scholl, D.T. DeVries, T.J. and Barkema, H.W. (2013). Herd-level relationship between antimicrobial use and presence or absence of antimicrobial resistance in gram-negative bovine mastitis pathogens on Canadian dairy farms. Dairy Sci. 96 : pg. 1-12.

Sargeant, J.M., Leslie, K.E., Shirley, J.E., Pulkrabek, B.J. and Lim, G.H. (2001). Sensitivity and specificity of somatic cell count and California mastitis test for identifiying intramammary infection in early lactation. J. Dairy Sci. 84, pg. 2018-2024.

Schalm, O., Noorlander, D., 1957. Experiments and observations leading to the development of California mastitis test. Journal of American Veterinary Medical Association 130, pg. 199-204.

Sharma, N., Singh, N.K., Bhadwal, M.S. (2011). Relationship of somatic cell count and mastitis: an overview. Asian-Australas J Anim Sci 24: pg. 429-438.

Sordillo, L.M. and Aitken. S.L. (2009). Impact of oxidative stress on the health and immune function of dairy cattle. Vet. Immunol. Immunopathol. 128: pg. 104-109.

Taponen, S., Salmikivi, L., Simojoki, H., Koskinen, M.T. and Pyorala, S. (2009). Real-time polymerase chain reaction-based identification of bacteria in milk samples from bovine clinical mastitis with no growth in conventional culturing. J. Dairy Sci. 92: pg. 2610-2617.

Trajcev, M., Popovski, Z.T., Nakov, D., Dimitrievska, B.P., Porcu, K., Petrovska, M., Jankoska, G. 2009. Characterisation of resistance of Streptococcus Spp. and Staphylococcus Spp. isolated from cow's milk. 4-th international congress of microbiologists of Macedonia - Book of abstracts, Macedonian medical review, year 63 (supl. 77), pg. 1-87.

Trajcev, M., Petrovska, M., Nakov, D., Jankoska, G. 2010. Therapy of subclinical mastitis in dairy cows. Yearbook of the Faculty of agricultural science and food, vol. 55, Skopje, pg. 117-128.

Wallace, J.A., Leslie, K.E., Dingwell, R.T., Schukken, Y.H., Baillargeon, P. (2002). An evaluation of a diagnostic and treatment protocol for intramammary infections in early postpartum dairy cows. Proc Annu Meet National Mastitis Council: pg. 159-160.

White, L.J., Lam, T.J., Schukken, Y.H., Green, L.E., Medley, G.F., Chappell, M.J. (2006). The transmission and control of mastitis in dairy cows: a theoretical approach. Prev. Vet. Med. 74, pg. 67-83. 